\title{
The four-year fight for biological art
}

Steven Kurtz, an art professor at the State University of New York at Buffalo, was cleared in April of wire and mail fraud charges, four years after the FBI seized art supplies from his home that included laboratory equipment and bacterial cultures. Kurtz is a founding member of the Critical Art Ensemble, which recently exhibited an installation called Immolation at the Foundation for Art and Creative Technology in Liverpool, UK, showing the effects of incendiary weapons on samples of human skin.

\section{How does it feel now the court case is finally over?}

It's really kind of odd. You would think that I would be feeling light as a feather and dancing down the street. But quite the opposite, it's more like having some kind of post-traumatic stress disorder. It's only in my more practical mind that I'm very happy about it all. After four years it's hard to come down out of fight mode, and it's hard to believe that it's over.

\section{What were you working on when you were arrested?}

We had just completed a piece called Free Range Grain where we tested unlabelled food in Europe to see if it was free of GMOs [genetically modified organisms]. We were coming back to do it in the United States, where we were going to test labelled organic foods. We were hoping to elicit further conversation about what it would mean if, say, a handful of corporations controlled the food supply. We were ready to open the project at Mass MoCA [Massachusetts Museum of Contemporary Art in North Adams] when I was arrested and all my materials were confiscated by the FBI.

The second thing that we were doing was investigating the history of germ warfare and why in most countries the plug has been pulled. We were just interested in presenting to the public a more rational history of it, rather than this kind of hysterical response that the Bush administration threw on the public.

You can see why the FBI wouldn't be pleased with either of these things.

The second project you mentioned, Marching Plague, involved throwing benign bacteria at guinea pigs, referencing an old British military experiment.

Yes, it did.

\section{Has the US Department of Justice} returned any of your materials?

That's the next fight for me: to try to get my lab equipment back and other things that they took, like my computers and books.

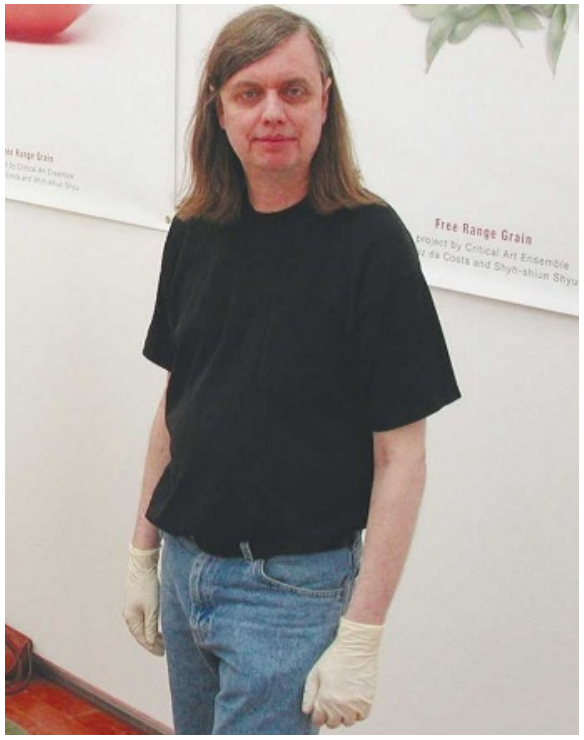

The government alleged that you and your colleague Robert Ferrell exchanged bacterial cultures in an unauthorized manner. What happened?

[Robert] did provide us with bacterial samples. This is the most ironic thing of the whole case, because we could have bought them ourselves. When we use bacteria in our projects, it often makes cultural institutions nervous because they don't know about bacteria. We knew this, and we thought that the best way to calm the nerves of cultural institutions that don't generally have a scientist consultant on board was if we could provide them with one. We were trying to make everyone feel safer and even get rid of the perception that there could possibly be a danger, which is what ended up actually getting us in trouble.

\section{Has the high-profile nature of the case} affected your collaboration with scientists? For our more recent projects we've either gone to Europe to do them or to Australia. In a way, our practice got expatriated a little bit after this mishap. The FBI was very thorough about going round to all the cultural institutions and labs we worked with and intimidating and threatening them. It had the effect of almost classifying science to make sure it's further alienated and pushed away from the public.

\section{It sounds like your art is about science education.}

One of the things we're really interested in is being some kind of mediator - some type of conduit - between the sciences and the public who are outside the sciences. If we're going to understand how the results of science are going to be placed into political economy and want to have some accountability there, the only way that can be done is through informed citizenship. And we want to promote that.

\section{Will you continue to work on biologically inspired art?}

We're very interested in continuing the line of anti-war work. That's probably going to be our main subject, but we always seem to somehow fold back in, or intersect back in, life sciences' role in the war economy.

\section{How would you characterize the climate in} the US art community after $\mathbf{9 / 1 1}$ ?

It has just been horrible. We're talking about the government pressure on doing activities that are perfectly legal. We're talking about activities that at one time in this country were considered a great idea, like amateur science. Say someone wants to have a laboratory in their house. I guess not a lot of people have that any more, so that's weird. And because it's weird, it's suspicious. And because it's suspicious, we have to think it's probably terrorism.

How do you function culturally if that is the structure? All the FBI is protecting us from in that way is stuff that's weird, not terrorists. And if you're an artist, your job is not to be a part of the everyday and the usual. You're supposed to go to the opposite end to find new ways of thinking about culture and its images, to try to reframe issues in new and exciting ways. And in so doing you're going to do weird stuff. If weird is suspicious and suspicious is going to be equated with terrorism, then the arts and culture are in a lot of trouble - and we are.

Interview by Rachel Courtland. 